\title{
Analyses of the Proficiency Testing Program and the Performance of Qualitative Reagents for Rheumatoid Factor
}

Jongwon $\mathrm{Oh}$ and Hyung-Doo Park

Department of Laboratory Medicine and Genetics, Samsung Medical Center, Sungkyunkwan University School of Medicine, Seoul, Korea

\author{
Corresponding author: \\ Hyung-Doo Park \\ Department of Laboratory \\ Medicine and Genetics, Samsung \\ Medical Center, Sungkyunkwan \\ University School of Medicine, \\ 81 Irwon-ro, Gangnam-gu, Seoul \\ 06351, Korea \\ Tel: $+82-2-3410-0290$ \\ Fax: +82-2-3410-2719 \\ E-mail: nayadoo@hanmail.net \\ pISSN: 2384-2458 \\ elSSN: 2288-7261
}

\begin{abstract}
Background: Rheumatoid factor (RF) is used as one of the diagnostic criteria for rheumatoid arthritis. The purpose of this study was to evaluate qualitative RF reagents used in clinical laboratories in Korea, and to provide basic data that can be used as a reference to improve the quality of RF testing.

Methods: We reviewed the proficiency testing results for RF from the Korean Association of External Quality Assessment Service (KEQAS) and College of American Pathologists. Moreover, we evaluated five commercially available RF qualitative reagents, including LabSlide RF (IVD Lab Co., Korea), ASAN RA Latex Reagents (Asan Pharmaceuticals Co., Korea), RaPET RF (Stanbio Laboratory, USA), RF Latex Test (Pulse Scientific Inc., Canada), and RF-100 (Teco Diagnostics, USA). Commercially available quality control materials, calibrators, and pooled sera were used in this study. The consistency of qualitative reagents and Kappa statistics were calculated based on the quantitative values of the quality control materials and the mixed sera.

Results: Up to $51.5 \%$ of high concentration samples were reported as negative in KEQAS. RF qualitative reagent test results were not consistent among reagent types. The consistency of the qualitative and quantitative test results was between $51 \%$ and $100 \%$, and the kappa statistics varied depending on the reagent manufacturer.

Conclusions: Measurement of RF qualitative reagents used in domestic clinical laboratories was not consistent with the quantitative values, and hence it is necessary to improve the consistency and verify the adequacy of the cut-off value.
\end{abstract}

(J Lab Med Qual Assur 2019;41:105-110)

Key Words: Rheumatoid factor, Rheumatoid arthritis, Proficiency testing, Quality control

Received December 27, 2018, Revision received February 11, 2019, Accepted February 26, 2019
서론

류마티스 관절염은 대표적인 자가면역질환으로 일반적으로 인구의 $1 \%$ 에서 발생하며, 여성에게 호발하는 만성진행성 염 증질환이다. 류마티스 관절염은 표준화된 검사법이 없기 때문 에 임상증상, 신체검사, 진단검사 소견, 영상검사 소견 등을 종 합하여 진단하게 된다. 1987 년에 개정된 미국 류마티스학회의 류마티스 관절염 진단기준에 의하여 일곱 가지 항목 중 네 가 지 이상을 충족시키면 류마티스 관절염으로 진단하고, 그 중 진단검사 소견으로는 혈청 류마티스인자(rheumatoid factor, $\mathrm{RF}$ ) 양성만 포함되어 있었다[1]. 이후 2010년에 미국 류마 티스학회와 유럽 류마티스학회의 공동연구에 의해 새로운 분
류기준이 발표되었으며, 당시 기준에 혈청 RF와 항 cyclic citrullinated peptide 항체검사가 포함되었다[2]. 따라서 RF 는 류마티스질환이 의심되는 환자들에게 필수적인 검사로 임 상검사실에서 많이 시행되고 있다.

$\mathrm{RF}$ 는 면역글로불린 immunoglobulin $\mathrm{G}$ ( $\mathrm{IgG}$ )의 Fc portion 에 결합하는 자가항체이며, 류마티스 관절염 환자의 60\%-80\% 에서 양성인 것으로 알려져 있다. RF의 검사방법은 1956 년 라텍스응집법에 의한 정성검사법이 처음으로 개발되었으며, 이후 효소결합면역측정법(enzyme-linked immunosorbent assay), 방사면역측정법(radioimmunoassay), 면역혼탁측정 법(Immunoturbidimetric assay) 등이 개발되어 정량검사가 가능하게 되었다[3]. RF는 류마티스 관절염의 발병에 대한 중 
요한 예측인자인데, 정량검사법은 정량값을 추적 관찰하면서 류마티스 관절염 환자의 질병 진행양상 등을 평가할 수 있고 자 동화된 검사장비를 이용하여 대용량 검체 처리가 가능하다는 장점이 있다. 이에 비해 정성검사법은 대용량 검체 처리 및 결 과 해석에 어려움이 있지만, 검사 수행의 간편함과 값싼 가격 경쟁력 등의 장점으로 인하여 건강검진이나 선별검사 용도로 여전히 많은 임상검사실에서 사용되고 있다. 그러나 라텍스응 집법을 이용한 정성검사의 특성 때문에 판독자에 따라 결과가 다르게 판독될 가능성이 있고, 상용화된 $\mathrm{RF}$ 검사시약 간 판독 결과의 불일치가 관찰된 바 있어, 양성, 음성 판정에 있어서도 차이가 있을 수 있다고 보고되었다[3,4].

$\mathrm{RF}$ 검사에 사용되는 시약은 다양한데, 검사방법 또는 시약 에 따라 $\mathrm{RF}$ 검사결과가 달라지는 것이 보고된 바 있다[3,4]. 또한 $\mathrm{RF}$ 의 정성검사 간 상관성 및 정량검사 간 상관성에 비하 여 정성검사와 정량검사 간의 상관성이 낮은 것으로 보고되었 다[5]. $\mathrm{RF}$ 검사결과는 류마티스 관절염의 진단 및 치료 결정 에 중요한 역할을 하므로 서로 다른 RF 검사시약의 유용성을 평가하는 것은 중요하다[6]. 그러나 대한임상검사정도관리협 회에서 수행 중인 신빙도조사 단백면역프로그램을 살펴보면 $\mathrm{RF}$ 항목의 정성 및 정량검사에 동일한 정도관리물질을 사용 하였음에도 불구하고, 정량검사 결과와 정성검사 결과가 불일 치한 경우가 상당수 발생하였다[7]. 본 연구에서는 지난 신빙 도조사프로그램의 $\mathrm{RF}$ 검사항목 결과를 분석하고, 국내 임상 검사실에서 사용되는 $\mathrm{RF}$ 정성검사의 결과와 정량검사의 결과 를 비교 평가하여 $\mathrm{RF}$ 검사의 질 향상을 위한 참고자료로 활용 될 수 있는 기초자료를 제공하고자 하였다.

\section{재료 및 방법}

\section{1. 대상}

대한임상검사정도관리협회 신빙도조사 단백면역검사프로 그램은 연 2회 수행하며, 매회 3개의 정도관리물질을 사용한 다. 2016년과 2017년 각각 1, 2차와 2018년 1차 신빙도조사프 로그램 $\mathrm{RF}$ 검사결과를 분석하였으며 미국 병리학회(College of American Pathologist, CAP)에서 주관하는 국외 외부정도 관리프로그램 결과를 함께 분석하여 국내 · 외 동료집단(peer group) 결과를 비교하였다. 또한 국내 시판 중인 $\mathrm{RF}$ 정성검 사 시약제품 5 종을 대상으로 검사정보지를 취합하여 기준치 (cut-off)를 확인하였으며 시약 구매 후 실험을 시행하여 기준 치 적절성을 평가하였다. 해당 시약들은 LabSlide RF (IVD Lab Co., Suwon, Korea), ASAN RA Latex Reagent (Asan Pharmaceuticals Co., Seoul, Korea), RaPET RF (Stanbio
Laboratory, Boerne, TX, USA), Rheumatoid Factor Latex Test (Pulse Scientific Inc., Burlington, ON, Canada), RF100 (Teco Diagnostics, Anaheim, CA, USA) 등이었다. $\mathrm{RF}$ 정성검사 시약의 검사원리는 전부 라텍스응집법이었다. RaPET RF, Rheumatoid Factor Latex Test, RF-100 등 3 종의 시약에는 양성 대조물질이 포함되어 있었지만, LabSlide $\mathrm{RF}$ 와 ASAN RA Latex Reagent 등 2종의 시약에는 포함되 어 있지 않았다.

\section{2. 실험재료}

1 차 실험은 10 가지 농도의 상품화된 정도관리물질과 보정 물질을 사용하여 수행하였으며, 2 차 실험은 자가제조한 혼주 혈청 5 가지 농도와 상품화된 정도관리물질 1 개를 사용하여 평가하였다. 1차 실험에 사용한 상품화 물질은 Rheumatoid Factor Calibrator Series Level 1-5 (Randox Laboratories, Crumlin, UK), Specific Protein Control Level 1, 3 (Randox Laboratories)과 Liquicheck Rheumatoid Factor Level 1-3 (Bio-Rad Laboratories Inc., Hercules, CA, USA)이었으며, 2차 실험에 사용한 정도관리물질은 Liquichek Immunology Control Level 1 (Bio-Rad Laboratories Inc.)이었다. 또한 삼성서울병원 진단검사의학과에 $\mathrm{RF}$ 검사가 의뢰된 혈청 검 체를 혼주하여 정량값을 $10 \mathrm{IU} / \mathrm{mL}$ 미만, $10-15 \mathrm{IU} / \mathrm{mL}, 20$ $25 \mathrm{IU} / \mathrm{mL}, 25-30 \mathrm{IU} / \mathrm{mL}, 100 \mathrm{IU} / \mathrm{mL}$ 초과의 농도가 되도 록 제조하여 정성검사 시약의 응집 여부를 판정하였다. 상품화 된 정도관리물질과 자가 제조한 혼주 혈청의 정량값은 Roche Modular E170 (Roche Diagnostics, Mannheim, Germany) 장비로 2 번 측정하여 평균값을 구하였다. 시약 lot 간 검사결과 차이 여부를 확인하기 위하여 1 차 실험과 2차 실험에서 $\mathrm{RF}$ 정 성시약 lot을 변경하여 시행하였다.

\section{3. 판정 및 분석}

1 차 실험에서는 10 가지 농도의 상품화 물질을 $\mathrm{RF}$ 정성시약 제조사의 지침에 따라 각각 8 회씩 분주한 후 판독하였다. 2 차 실험에서는 5 가지 농도의 자가제조한 혼주 혈청과 1 가지 농 도의 상품화된 정도관리물질을 각각 5 회씩 분주한 후 판독하 였다. 각 실험에서 검사결과 판독의 객관성을 위하여 두 명의 검사자가 동시에 맨눈으로 판독하였으며 제조사의 지침에 따 라 양성 및 음성으로 판정하였다. 입자가 보이지만 명확한 응 집상을 관찰할 수 없는 위양성의 경우 음성으로 판단하였다. 정도관리물질과 혼주 혈청의 정량값을 기준으로 정성시약의 일치도 및 kappa 통계량을 계산하였다. 


\section{결과}

신빙도조사프로그램의 $\mathrm{RF}$ 정량검사 및 정성검사 통계는 Table 1에 정리하였으며 CAP에서 주관하는 외부정도관리의 $\mathrm{RF}$ 결과는 Table 2에 정리하였다. 국내 신빙도조사프로그램 에서 1 번 검체 정량값의 중앙값은 $20 \mathrm{IU} / \mathrm{mL}$ 근처로 대부분의 정성시약 기준치 근처 수치로 출제되었으며, 2 번 검체와 3 번 검체의 정량값은 각각 $30-40 \mathrm{IU} / \mathrm{mL}, 40-50 \mathrm{IU} / \mathrm{mL}$ 의 범위로 정성시약 기준치를 초과하는 수치를 보였다. $\mathrm{CAP}$ 에서 주관하 는 외부정도관리의 경우, 낮은 농도 검체는 대부분 $10 \mathrm{IU} / \mathrm{mL}$ 이하의 범위였으며, 높은 농도 검체는 $100 \mathrm{IU} / \mathrm{mL}$ 이상을 보 였다. 국내 신빙도조사프로그램과 CAP에서 주관하는 외부정 도관리에서 유사한 농도의 $\mathrm{RF}$ 물질은 없었다.

1,2 차 실험에 사용한 상품화 정도관리물질과 혼주 혈청의 측정된 정량 평균값, 제조사 정보지의 목적값 및 범위, $\mathrm{RF}$ 정 성시약의 lot 번호 및 기준치 정보와 판독결과는 Table 3에 정 리하였다. 5 개의 정성시약 중 3 개 시약은 기준치가 $20 \mathrm{IU} / \mathrm{mL}$ 이었으며 2 개는 각각 $8 \mathrm{IU} / \mathrm{mL}$ 과 $10 \mathrm{IU} / \mathrm{mL}$ 이었다. 두 명의 검사자 간 판독결과는 모두 일치하였다. 실험결과 모든 정성 시약은 $10 \mathrm{IU} / \mathrm{mL}$ 이하의 범위에서 음성 소견을 보였으며, 30 $\mathrm{IU} / \mathrm{mL}$ 이상의 농도에서는 대부분 양성 소견을 보였지만 일 부 시약에서는 음성 소견이 관찰되었다. Table 4에 각 $\mathrm{RF}$ 정 성시약의 정량값과의 일치도 및 kappa 통계량을 기술하였다.
정성시약과 정량값과의 일치도는 $51.4 \%-100.0 \%$ 를 보였으며, kappa 통계량은 0.40 에서 1.00 까지의 값을 보였다.

\section{고찰}

2016년부터 2018년까지 대한임상검사정도관리협회에서 시 행한 신빙도조사사업의 단백면역프로그램을 분석한 결과, $\mathrm{RF}$ 정성검사 결과가 정량검사 결과와 일치하지 않는 현상이 많이 관찰되었다. 2016-2017년 2년간의 신빙도조사사업 결과를 분 석해 보면 $\mathrm{RF}$ 정량값이 $20 \mathrm{IU} / \mathrm{mL}$ 내외인 1 번 검체의 경우, 정성 결과에서 양성을 보인 경우는 $50 \%$ 내외였다. 기준치가 $20 \mathrm{IU} / \mathrm{mL}$ 인 정성시약의 경우 정성 결과가 음성으로 판독될 가능성은 있으나 예상되는 결과보다 더 많은 음성 판정이 관찰 되었다. 2 번, 3 번 검체의 경우 정량검사를 수행한 대부분의 기 관에서 $30 \mathrm{IU} / \mathrm{mL}$ 이상으로 보고하였으므로 정성 검사결과는 대부분 양성으로 판정되어야 하지만, 음성으로 판정된 경우가 2 번 검체는 $35.0 \%-51.5 \%, 3$ 번 검체는 $4.5 \%-44.8 \%$ 로 상당 히 많았다. 정성시약 기준치를 상회하는 2 번, 3 번 검체에서 음 성으로 판정된 경우가 $30 \%$ 이상이었다는 것은 $\mathrm{RF}$ 측정에서 정성 검사시약의 정확도가 떨어지는 것을 의미한다. 제일 높 은 농도인 3번 검체(40-50 IU/mL)는 2017년 2차와 2018년 1 차 신빙도조사사업에서 양성률이 증가했는데, 2 번 검체(30-40 $\mathrm{IU} / \mathrm{mL}$ )의 경우 2017년 2차에서는 여전히 낮은 양성률을 보

Table 1. Proficiency testing results for rheumatoid factor from the Korean Association of External Quality Assessment Service

\begin{tabular}{lcccc}
\hline Year/round & CP-01 (IU/mL, \%) & CP-02 (IU/mL, \%) & CP-03 (IU/mL, \%) & $\begin{array}{c}\text { No. of quantitative/ } \\
\text { qualitative test results }\end{array}$ \\
\hline 2016/first & $22.3(54.7)$ & $33.1(56.8)$ & $44.0(67.4)$ & $310 / 95$ \\
2016/second & $20.0(44.8)$ & $34.1(56.3)$ & $47.0(55.2)$ & $314 / 96$ \\
2017/first & $19.9(43.0)$ & $34.0(65.0)$ & $46.1(70.0)$ & $334 / 100$ \\
2017/second & $20.3(64.2)$ & $33.0(48.5)$ & $45.7(95.5)$ & $463 / 134$ \\
2018/first & $20.4(72.3)$ & $36.1(95.3)$ & $45.3(97.3)$ & $402 / 148$ \\
\hline
\end{tabular}

Values are presented as median (positive \%), unless otherwise stated.

Table 2. Proficiency testing results for rheumatoid factor from the College of American Pathologists

\begin{tabular}{lccccc}
\hline Year/round & RF-01 (IU/mL, \%) & RF-02 (IU/mL, \%) & RF-03 (IU/mL, \%) & RF-04 (IU/mL, \%) & RF-05 (IU/mL, \%) \\
\hline 2016/first & $5(1.9)$ & $5(1.4)$ & $189(99.9)$ & $193(99.4)$ & $6(2.4)$ \\
2016/second & $242(99.4)$ & $134(98.1)$ & $9(8.5)$ & $10(9.3)$ & $131(97.7)$ \\
2017/first & $148(99.3)$ & $2(2.1)$ & $247(99.7)$ & $96(95.3)$ & $3(2.1)$ \\
2017/second & $113(99.3)$ & $2(3.8)$ & $3(3.7)$ & $210(99.7)$ & $115(98.8)$ \\
2018/first & $228(99.6)$ & $196(100.0)$ & $136(98.4)$ & $3(0.3)$ & $3(0.7)$ \\
\hline
\end{tabular}

Values are presented as median (positive \%), unless otherwise stated. 
Journal of LABORATORY MEDICINE and QUALITY ASSURANCE

Jongwon Oh et al • Evaluation of RF Qualitative Reagents

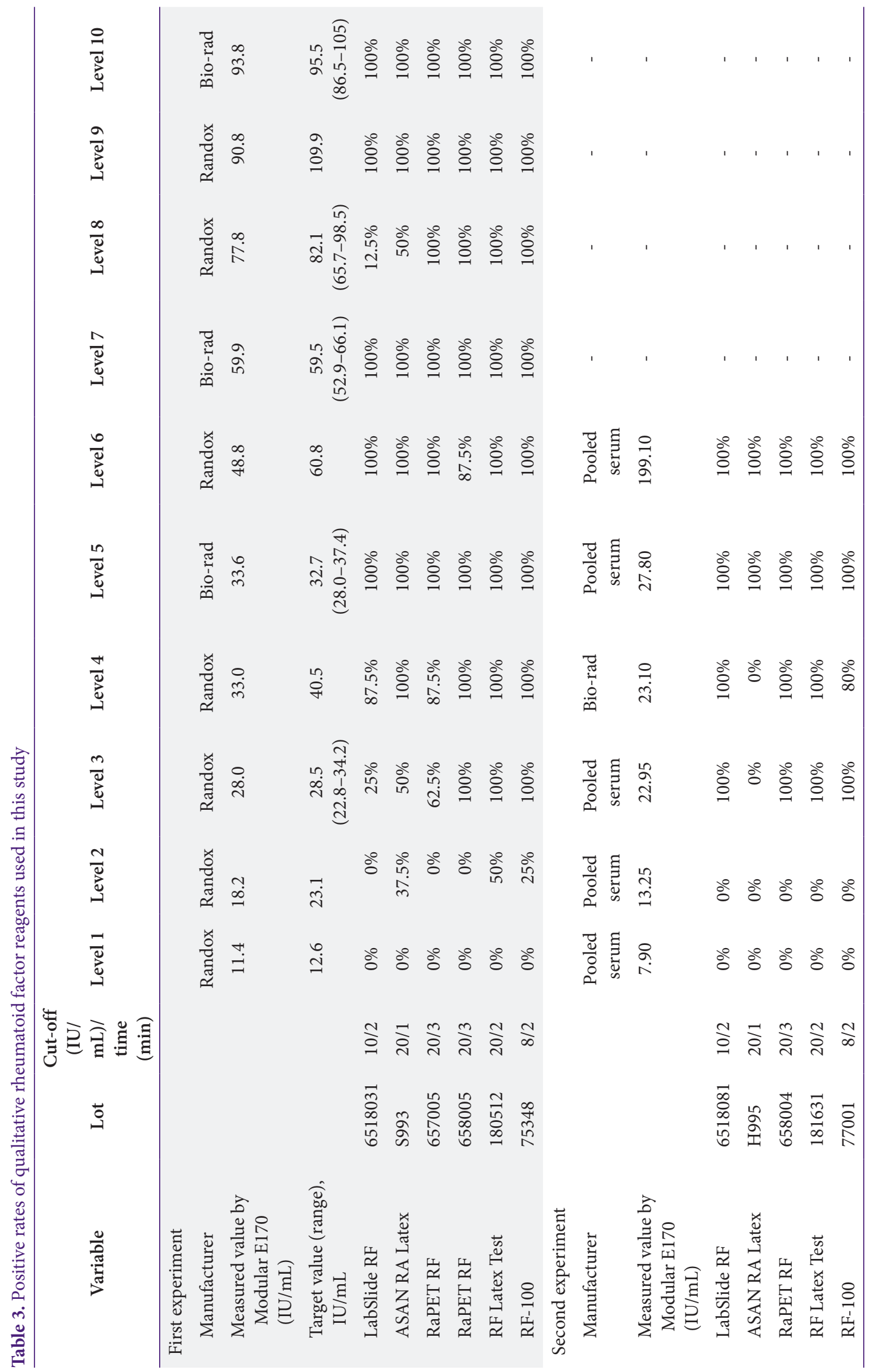


Journal of LABORATORY MEDICINE and QUALITY ASSURANCE

Jongwon Oh et al • Evaluation of RF Qualitative Reagents

Table 4. Agreement rates and Kappa statistics between rheumatoid factor qualitative and quantitative reagents

\begin{tabular}{|c|c|c|c|c|c|}
\hline \multirow[b]{2}{*}{ Variable } & \multicolumn{5}{|c|}{ Reagents } \\
\hline & LabSlide RF & $\begin{array}{l}\text { ASAN RA } \\
\text { Latex }\end{array}$ & RaPET RF & RF Latex Test & RF-100 \\
\hline Lot & 6518031 & S993 & $657005 / 658005$ & 180512 & 75348 \\
\hline Agreement rate (\%) & 62.5 & 86.2 & $95.0 / 98.8$ & 95.0 & 82.5 \\
\hline \multicolumn{6}{|l|}{ Second experiment } \\
\hline Lot & 6518081 & H995 & 658004 & 181631 & 77001 \\
\hline Agreement rate (\%) & 83.3 & 66.7 & 100.0 & 100.0 & 51.4 \\
\hline Kappa statistic & 0.57 & 0.40 & 1.00 & 1.00 & 0.80 \\
\hline
\end{tabular}

Abbreviation: NA, not available.

이다가 2018년 1차에서 $95.3 \%$ 로 양성률이 증가했다. 이와 같 은 정확도의 개선은 각 $\mathrm{RF}$ 정성시약 제조사에서 정확도를 향 상시키고자 하는 노력의 결과일 수도 있지만, lot 변화에 따른 일시적 현상일 가능성도 배제할 수 없다. 동일한 제조사 시약 을 사용하더라도 lot에 따라 다른 결과를 보일 수 있으므로 시 약의 lot 관리를 통해 정확성을 계속 유지하며, 기준치 이상의 물질에서 양성 결과가 일관되게 보이도록 개선할 필요가 있다.

$\mathrm{RF}$ 정성시약은 감마글로불린으로 코팅된 라텍스인자를 함 유하고 있으며, 인간 감마글로불린을 사용한 시약과 토끼 감마 글로불린을 사용한 시약 간 결과 불일치가 있을 수 있음이 알 려져 있으나 이번 연구에 사용한 시약들은 모두 인간 감마글로 불린을 사용한 경우였다[4]. 한편 $\mathrm{RF}$ 정성시약 평가에서 제조 사에 따라 같은 물질에서도 다양한 결과를 보였는데, 제조사의 기준치가 시약의 실제 성능보다 낮게 잘못 설정되어 있어 신 빙도조사사업 결과에도 영향을 주었을 가능성이 있다. 특 히 기준치가 $8 \mathrm{IU} / \mathrm{mL}$ 과 $10 \mathrm{IU} / \mathrm{mL}$ 인 시약들의 위음성 결과 가 많았는데, $\mathrm{RF} 18 \mathrm{IU} / \mathrm{mL}$ 물질에서 대부분 음성 결과를 보 여서 신빙도조사사업의 불일치 결과에 영향을 주었을 것으로 생각되며, 해당 시약의 경우 기준치의 검증이 적절히 이루어져 야 할 것이다. 신빙도조사사업의 고농도 3 번 검체와 유사한 40 $\mathrm{IU} / \mathrm{mL}$ 이상의 물질로 평가한 본 연구에서도 대부분 양성 소 견을 보였다. Prozone 효과로 고농도의 시료에서 반대로 낮은 값이 측정될 가능성이 있다고 알려져 있으므로 $70 \mathrm{IU} / \mathrm{mL}$ 이 상의 정량값에서 정성시약이 음성을 보인 경우는 prozone 효 과에 의한 가능성을 고려해야 한다. 류마티스 관절염 환자에서 실제 $\mathrm{RF}$ 양성임에도 불구하고 혈청 중의 과다 항체량으로 인 해 음성 혹은 약양성 반응으로 나타나는 prozone 효과가 있을 수 있으므로 정성검사 판독 시 주의가 필요하다.

이번 실험에서 정성값과 정량값의 일치도는 시약 및 시약 lot에 따라 $51.4 \%$ 에서 $100 \%$ 까지 다양한 양상을 보였다. 같은 시약의 경우도 lot이 다른 경우 적게는 5\%에서 많게는 $30 \%$ 이상의 일치도 차이를 보여 시약 lot 관리의 중요성이 강조되 었다. Kappa 통계량도 시약 lot에 따라 편차가 심했으며 일부 시약은 lot 관리 및 정확도 개선이 필요할 것으로 생각한다. 실 험에서 낮은 일치도 및 kappa 통계량을 보인 RF 정성시약은 기준치 농도가 $10 \mathrm{IU} / \mathrm{mL}$ 이하인 시약들이었는데, 과거에 기 준치 농도를 $15,20,25 \mathrm{IU} / \mathrm{mL}$ 에 따라 조사한 연구에서는 기 준치 농도를 높여서 류마티스질환 진단의 특이도를 높이는 게 더 중요하다고 추천하였다[8]. 덴마크에서 진행된 류마티스 관절염이 없는 9,712 명을 대상으로 조사한 연구에서 $\mathrm{RF}$ 의 중 앙값은 $18 \mathrm{IU} / \mathrm{mL}$ 였으며[9], 국내 연구에서 류마티스 관절염 환자군의 $\mathrm{RF}$ 평균은 $377.1 \pm 614.2 \mathrm{IU} / \mathrm{mL}$ 인데 비하여 건강 대조군에서는 $1.9 \pm 8.5 \mathrm{IU} / \mathrm{mL}$ 를 보였다[10]. 류마티스 관절 염 환자들에서는 $100 \mathrm{IU} / \mathrm{mL}$ 이상의 수치를 보이는 경우도 종 종 보고되므로 너무 낮은 농도를 기준치로 정하면 실질적으로 류마티스질환 진단에 도움이 되기보다는 많은 위양성 결과를 초래하여 불필요한 추가검사를 유발할 것으로 여겨진다.

$\mathrm{CAP}$ 에서 주관하는 신빙도조사사업의 경우, $\mathrm{RF}$ 의 정성결 과 기관 간 일치도가 $90.7 \%-100 \%$ 로 우수한 결과를 보여주었 으나, 해당 외부정도관리물질의 정량값이 $10 \mathrm{IU} / \mathrm{mL}$ 이하거 나 $100 \mathrm{IU} / \mathrm{mL}$ 이상인 물질을 주로 사용하기 때문에 기관 간 일치도가 매우 높게 나온 것으로 보인다. 상대적으로 기준치 에 근접한 9-10 IU/mL의 농도물질을 사용한 경우에 90.7\%$91.8 \%$ 의 기관 간 일치도를 보임으로써 2-6 IU/mL의 농도물 질을 사용했을 경우의 $96.2 \%-99.7 \%$ 의 기관 간 일치도에 비해 서 낮은 경향을 보였다.

이번 연구에서 눈여겨볼 만한 것은 비슷한 농도의 혼주한 사 람 혈청 물질에 비하여 정도관리물질로 검사했을 때의 응집반 


\section{Journal of LABORATORY MEDICINE and QUALITY ASSURANCE}

Jongwon Oh et al • Evaluation of RF Qualitative Reagents

응속도가 더 느렸다는 점이다. 시료 종류에 따라 측정결과가 달라질 수 있음은 잘 알려져 있는데, 이번 연구에서도 정도관 리물질을 사용한 경우보다 혼주한 사람 혈청을 사용했을 때 위 음성이 더 적었으므로, 정도관리물질로 평가한 외부정도관리 결과에 비하여 실제 임상검사실에서 환자 검체로 검사했을 때 정성 시약에서의 위음성이 더 적게 발생했을 가능성이 있다.

이 연구의 제한점은 류마티스 관절염으로 진단된 환자들의 혈청으로 정성시약을 평가한 것이 아니어서 류마티스 관절염 진단에 있어서의 임상적 민감도와 특이도 등을 구할 수는 없었 다는 점이다. 또한 본 실험에서는 Roche Modular E170 장비 로 측정한 정량검사 결과를 정성검사 결과와 비교하였는데, 여 러 종류의 정량측정장비로 검사하여 정성검사 결과와 비교/평 가하는 것도 추가적으로 필요할 것이다.

결론적으로, 국내 임상검사실에서 사용되는 $\mathrm{RF}$ 정성시약은 정량값과 상당한 불일치를 보였으며, 많은 정성시약에 대해 정 확도의 개선 및 기준치의 적절성에 대한 검증이 필요할 것으 로 생각된다. 임상검사실에서 여건이 된다면 $\mathrm{RF}$ 측정은 정성 검사를 최소화하고 정량검사를 하는 것이 추천되지만, 부득이 한 상황에서는 정성검사를 시행해야 하는 경우가 있다. 1 차적 으로 제조사에서 시약의 정확성을 높이면서 시약성능을 평가 할 수 있는 대조물질을 추가하고, lot 간 변이 최소화 및 적절 한 기준치를 선정하려는 노력이 필요하다. 2 차적으로 정성검 사 시약 사용자는 적절한 정도관리물질이나 임상 검체를 이용 하여 시약의 적절성 및 시약 lot 간 수행능을 정기적으로 검증 하고, 외부정도관리에 참여하여 정확도 여부를 확인할 필요가 있다. $\mathrm{RF}$ 정성시약의 질을 개선하고 정확한 결과를 얻기 위해 제조사와 사용자 모두 노력해야 할 것이다.

\section{감사의 글}

이 논문은 대한임상검사정도관리협회 2018년 학술연구비 (2018-01) 지원에 의해 이루어진 것이다.

\section{REFERENCES}

1. Arnett FC, Edworthy SM, Bloch DA, McShane DJ, Fries JF, Cooper NS, et al. The American Rheumatism Associa- tion 1987 revised criteria for the classification of rheumatoid arthritis. Arthritis Rheum 1988;31:315-24.

2. Aletaha D, Neogi T, Silman AJ, Funovits J, Felson DT, Bingham CO 3rd, et al. 2010 Rheumatoid arthritis classification criteria: an American College of Rheumatology/ European League Against Rheumatism collaborative initiative. Ann Rheum Dis 2010;69:1580-8.

3. Goddard DH, Moore ME. Common tests for rheumatoid factors: poorly standardized but ubiquitous. Arthritis Rheum 1988;31:432-5.

4. Falkenburg WJ, von Richthofen HJ, Koers J, Weykamp C, Schreurs MW, Bakker-Jonges LE, et al. Clinically relevant discrepancies between different rheumatoid factor assays. Clin Chem Lab Med 2018;56:1749-58.

5. Jaspers JP, van Oers RJ, Leerkes B. Nine rheumatoid factor assays compared. J Clin Chem Clin Biochem 1988;26:863-71.

6. Quartuccio L, Fabris M, Salvin S, Atzeni F, Saracco M, Benucci $\mathrm{M}$, et al. Rheumatoid factor positivity rather than anti-CCP positivity, a lower disability and a lower number of anti-TNF agents failed are associated with response to rituximab in rheumatoid arthritis. Rheumatology (Oxford) 2009;48:1557-9.

7. Park HD. Annual report on the external quality assessment scheme for special protein in Korea (2017). J Lab Med Qual Assur 2018;40:85-91.

8. Thammanichanond D, Kunakorn M, Kitiwanwanich S, Attamasirikul K, Nantiruj K. Raising rheumatoid factor cutoff helps distinguish rheumatoid arthritis. Asian Pac J Allergy Immunol 2005;23:165-8.

9. Nielsen SF, Bojesen SE, Schnohr P, Nordestgaard BG. Elevated rheumatoid factor and long term risk of rheumatoid arthritis: a prospective cohort study. BMJ 2012;345:e5244.

10. Cho SY, Kang SY, Lee HJ, Lee WI. A comparative evaluation of the diagnostic value of anti-cyclic citrullinated peptide and rheumatoid factor in rheumatoid arthritis. Korean J Lab Med 2008;28:39-45. 